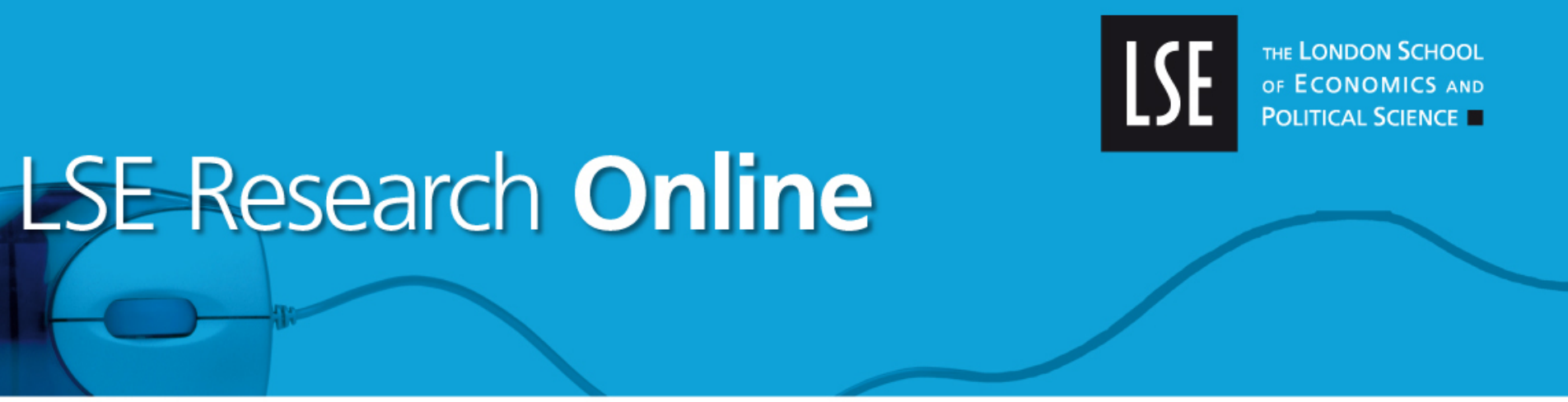

\title{
Irene Bucelli
}

The role of 'Autonomy' in teaching

expertise

\section{Article (Accepted version) \\ (Refereed)}

\section{Original citation:}

Bucelli, Irene (2017). The role of 'Autonomy' in teaching expertise. Journal of Philosophy of

Education 51, (3) pp.588-604. ISSN 0309-8249

DOI: $\underline{10.1111 / 1467-9752.12252}$

(C) 2017 The Philosophy of Education Society of Great Britain.

This version available at: http://eprints.Ise.ac.uk/85987/

Available in LSE Research Online: November 2017

LSE has developed LSE Research Online so that users may access research output of the School. Copyright $(\subset$ and Moral Rights for the papers on this site are retained by the individual authors and/or other copyright owners. Users may download and/or print one copy of any article(s) in LSE Research Online to facilitate their private study or for non-commercial research. You may not engage in further distribution of the material or use it for any profit-making activities or any commercial gain. You may freely distribute the URL (http://eprints.Ise.ac.uk) of the LSE Research Online website.

This document is the author's final accepted version of the journal article. There may be differences between this version and the published version. You are advised to consult the publisher's version if you wish to cite from it. 


\section{The Role of 'Autonomy’ in Teaching Expertise}

\section{IRENE BUCELLI}

Debates around the effects of 'new public measures' emphasise changes to teachers' practices, role and expertise. While critics lament a 'deprofessionalisation' of teaching, in some countries, such as England, the current rhetoric stresses the government's trust in teachers and talk of 'professional autonomy' has come to the forefront. In light of this, a more rigorous understanding of the role of autonomy in teaching expertise seems necessary. This paper asks whether the notion of autonomy is significant to teachers' roles and activities, and explores how autonomy bears on our conception of teaching expertise. The first part of the paper clarifies the very conception of autonomy that is employed in much philosophical discussion. I will argue that the notion of autonomy is problematic: it conflates rather different psychological, phenomenological and normative elements. When we clarify these ideas we can see how some of these aspects are in fact extremely relevant to our conception of the role of teachers and to our understanding of teaching practice. In the second part of the paper, these concepts are employed to clarify public debates surrounding teachers' autonomy, comparing England and Scotland. I will claim that the kinds of knowledge and abilities constituting teaching expertise depend on our understanding of the role of teachers within an educational system and in relation to educational aims. This, in turn, has consequences for the way in which teaching expertise can be developed and/or hindered through policy.

\section{INTRODUCTION}

For a few decades now, debates around the effects of 'new public measures' in education have pointed to how the emphasis on increased accountability and high stakes testing has led to some worrying phenomena-such as narrowing of the curriculum, gaming and teaching to the test (Jacob, 2004; West and Pennell 2005) thus changing teachers' practices and roles. In these debates, losses of autonomy lamented by teachers mirrored what has been called a 'deprofessionalisation' of teaching (Barksdale-Ladd and Thomas, 2000; Webb et al., 2004). At the same time, in some countries, such as England, the current rhetoric stresses the government's trust in teachers and talk of 'professional autonomy' has come to the forefront (DfE, 2010). In light of this, a more rigorous understanding of the role of autonomy in teaching expertise seems necessary.

Definitions of teaching expertise are controversial (Cribb and Gewirtz, 2007; Maxwell, 2015; Winch, 2017). Teaching is a polymorphous ability (Winch, 2017) and while one can broadly assert that it comprises both subject knowledge and practical knowledge of how to present one's subject in a pedagogically effective way, it is very much a matter of dispute whether categories of teachers' knowledge such as technical knowledge about teaching and learning, as well as practical wisdom (Biesta, 2015), should be included in this conception. More generally, what these forms of knowledge amount to and what their relationships are, is a subject of debate. It remains a question whether they constitute the basis for claiming a specific teaching expertise (Maxwell, 
2015). The claim supported by this paper sees our specific understanding of these kinds of knowledge and abilities as fundamentally depending on our understanding of the role of teachers, within an educational system and in relation to educational aims. This, in turn, has consequences for the way in which teaching expertise can be developed and has practical implications, for example, in relation to policy arrangements in teachers' education.

The particular standpoint from which this paper tackles these issues revolves around asking whether the notion of autonomy is significant to teachers' roles and activities, and hence bears on our conception of teaching expertise. In order to answer this question, I will claim that it is essential to clarify the very notion of autonomy that is employed in much philosophical discussion. I will argue that the notion of autonomy is problematic: it conflates rather different psychological, phenomenological and normative elements. When we clarify these ideas we can see how some of these aspects normally subsumed under the concept of autonomy are in fact extremely relevant to our conception of the role of teachers and to our understanding of teaching practice. This in turn enables us to clarify public debates surrounding teachers' autonomy. My discussion therefore culminates in an analysis of current policy arrangements in England.

\section{CONCEPTIONS OF AUTONOMY}

The notion of autonomy occupies a central role in debates in moral philosophy and in philosophy of action. A prominent, neo-Kantian, position holds that human agency exhibits the distinctive feature of being self-controlled, self-governed and autonomous (Bratman, 2007; Frankfurt, 1971; Korsgaard, 2009; Velleman, 2007). It is by virtue of this capacity that humans are capable of being self-determined. This means that our actions are not the mere result of whatever state we are in, instead, they count as our doing: the 'agent is the source of, determines, directs, governs the action, and it is not merely the locus of a series of happenings, of causal pushes and pulls' (Korsgaard, 2009). This view identifies the condition of self-governance with the agent's reflective endorsement: with the commitment to his own doings by means of his reflective capacities. The notion of autonomy underlying reflective endorsement theories of agency entails that several characteristics of actions are standing or falling together. So, for example, a self-governed agent is, in these views, one that is active, self-controlled and who identifies with his motives. And vice-versa, when someone is alienated from his motives, he is passive in a way that diminishes his agency.

In philosophy of education, again some of these characteristics emerge in defining the concept. So, for example, autonomy can be generally understood as the condition in which an individual is able to choose and act upon the choice of a certain way of living. The autonomous person is one 'who determines how he or she should live according to their own, unpressured, picture of a worthwhile life' (White, 2003, p. 147); and who 'reflects independently and critically upon basic commitments, desires, and beliefs (...) and enjoys a range of meaningful life options from which to choose, upon which to act, and around which to orient and pursue one's life projects' (Reich, 2002, p. 46). While definitions vary, we find an emphasis that is similar to reflective endorsement theories on critical reflection (Brighouse, 2002) and the psychological structure of the agents' motives needed for self-determination (Morgan, 1996). Because individual self-determination of ends in life is a condition of individual flourishing and of participation in liberal, democratic societies (Christman, 1998; Gutman 1995), preparation for autonomy is considered as a central aim of 
education (Brighouse, 2002; Winch, 2002). Some see teachers' autonomy, in this sense of self-cultivation and self-determination, as necessary to foster students' own autonomy (Haydon, 1983; Higgins, 2011, p. 2). In general, much of the discussion surrounding autonomy has revolved around the interplay between the different actors in the educational field (institutions, parents, teachers and students) and their agency in relation to autonomy as an educational goal (Ben-Porath, 2009; Coleman, 2003; Wilson and Ryg, 2015). At the same time, autonomy is also understood as a much thinner notion: in terms of the discretion defining the scope of teachers' agency in relation to the multiple sources of accountability their practice is embedded in (Cribb and Gewirtz, 2007; Maxwell, 2015; Vedung, 2015). Much of this discussion has underscored the normative value of this discretion (as a precondition for the exercise of teachers' professional expertise, but also as a source of well-being for teachers as well as innovation and effectiveness) along with its limits (Cribb and Gewirtz, 2007). These discussions have emphasised the importance of appreciating the multidimensionality of the concept and focused on the complex interrelations of different actors at different levels of policy and practice. They also point out different modes of regulating such discretion, for example with different educational systems establishing different degrees of prescription and guidance in relation to different elements of teaching (Cribb and Gewirtz, 2007; Frostenson, 2015; Wermke and Salokangas, 2015).

Does the notion of autonomy play any role in our understanding of teaching expertise? Prima facie, an affirmative answer seems doubtful.

On the one hand, the discourse around the notion of autonomy appears either tangential to one pertaining to the nature of teaching and related expertise, or supporting a view that is in outright opposition to some influential theories of these. In fact, on the one hand, much of the discussion surrounding teaching has focused on understanding the forms of knowledge and abilities defining its expertise: for example, in respect to defining boundaries and relations of propositional and practical knowledge (Winch, 2010); something that in turn bears on the much contested possibility of defining areas of specialised knowledge in which teachers can lay claim to expertise (Maxwell, 2015). This debate sees a rich discussion about intellectualistic and non-intellectualistic models that suggest different conceptions, for example, of the role of theoretical knowledge in teaching and the use of principles to guide action (Winch, 2009). The concept of autonomy-especially when defined in terms of reflective endorsement-is grounding an extremely demanding picture of agency ${ }^{1}$ but it seems to have little or no bearing on this discussion about the forms of knowledge defining teaching expertise. Moreover, when autonomy is understood as 'discretion', it is conceived as a 'precondition' for the exercise of teaching expertise (Cribb and Gewirtz, 2007), rather than integral to our understanding of it.

Furthermore, much discussion has focused on the empirical generalisations providing the necessary conditions for the attribution of expertise to a person performing particular tasks. In this sense, the notion of expertise does not refer to the particular forms of knowledge and know-how that characterise teachers and teaching as an occupation. It rather refers to theories that specify generally the conditions for expert performance and skill acquisition, pointing at how expertise should be developed. These theories have been influential both among philosophical and educational commentators (Berliner, 1994, 2001): they provide a picture of a performance characterised not only by high quality but also conducted fluently, without reference to rules and theory. In fact, fluency theories hold that experts engage in a performance that is qualitatively different from that of novices or 
competent performers. An expert is not consciously choosing what to attend to and what to do, 'he or she does not solve problems. He or she does not even think. He or she just does what normally works' (Dreyfus, 2004, p. 180). Context-free rules, employing detached, analytic and deliberative thinking are gradually replaced by situational discriminations at the proficiency stage, while at the final 'expert' stage, both understanding of the task and deciding what to do is intuitive, fluid and involved. Experts act effortlessly and fluidly and, according to Dreyfus, arationally, because their thinking cannot be described as deductive or analytic (Dreyfus and Dreyfus, 2004). The conception of autonomy discussed so far seems to be at odds with this picture. In fact, when autonomy is associated with reflective endorsement, those 'immersed' actions that are characteristic of expert performance do not display the kind of self-consciousness required by autonomy. Dreyfus's (2002) 'mindless coping' entails that when I am engaged in one of these actions, I display merely a basic selfawareness. I know what I am doing and I am aware of being the agent who is doing it, but, as Gallagher and Marcel (1999) have argued, if we attempt to adopt a reflective stance, we alter our intentional structure, and 'the self who had been immersed in those projects is now abstracted from them' (p. 289). As a result, expert actions fall short of the requirements of autonomy and, consequently, of full-blown agency. Autonomy, and agency, seem to require that detached, analytic and deliberative stance excluded by Dreyfus's theory of expertise. ${ }^{2}$

In this scenario, I claim that it is essential that we clarify the very notion of autonomy discussed so far. By doing so, I will highlight how some aspects normally conflated under this term are central to understanding teaching practice and to defining a certain role for teachers. These distinctions will also point at how much of the discussion around teachers' discretion within certain educational systems conceals a particular normative conception of autonomy.

\section{RETHINKING ‘AUTONOMY’ IN TEACHING EXPERTISE}

I believe that the concept of autonomy, as it is normally employed in much philosophical discussion is fundamentally obscure. This 'overworked term' (Arpaly, 2003) conflates rather different psychological, phenomenological and normative elements. Where the literature distinguishes these different aspects, they are not immediately put to use in educational theory (Ashely, 2012; Arpaly, 2003; Feinberg, 1989).

Conditions of autonomy seem to encompass both a form of control over one's motives and an expression of the agent's identity (Dworkin, 1989; Frankfurt, 1986; Korsgaard, 2009). Some critics of the notion of autonomy distinguish authenticity from self-control (Arpaly, 2003; Sartre, 1946). My position here is that these two aspects of the agents' psychology are in fact distinct, and that by distinguishing them we can understand the role of authenticity in teaching. At the same time, autonomy seems to allude also to phenomenological notions such as the sense of activity or identification which, rather than pertaining to the agents' psychology, refer to the subjective experience of agency. Once we abandon a conception of autonomy that conflates these different phenomenological and psychological aspects we can explore how some of these elements play an important role in the development of teaching ability and in teaching practice.

The Experience of Autonomy, Identification and Self-Determination Theory 
When we distinguish these aspects we can, for example, focus our attention on theories such as Self-Determination Theory (SDT), that have been at the forefront of the research investigating the experience of autonomy and its importance in the delivery of public services. Deci and Ryan's (2000) influential work distinguishes two poles of individual motivation: on the one hand, 'external regulation' is the least autonomous form of motivation, for example connected to external punishment or reward. On the other hand, intrinsic motivation corresponds to the genuine spontaneous phenomenological experience of an 'internal perceived locus of causality'. In between these poles, SDT describes other forms of motivation, and in particular points to how extrinsic motivation can be more autonomous when people identify with the importance of the behaviour or integrate it with their sense of self. SDT is specifically focused on the social and environmental factors that facilitate or undermine intrinsic motivation. Ryan and Deci's experimental work (Ryan and Deci 2000; 2006) ascribes a central role to feelings of autonomy: in fact, more autonomous forms of motivation (either as intrinsic motivation or identification) contribute not just to people's wellbeing but to the sustainability of people's behaviour and long-term behavioural change. Inasmuch as the development of teaching ability and the acquisition of expertise require effort, motivation and practice, they find in the experience of autonomy a factor that can sustain this process of acquisition. This is the case, for example, because non-autonomous regulation, which involves inner conflict, is connected to ego-depletion ${ }^{3}$ (Moller et al., 2006a, 2006b). Ego-depletion refers to the phenomenon for which 'the self's acts of volition draw on some limited resource, akin to strength or energy and that, therefore, one act of volition will have a detrimental impact on subsequent volition' (Baumeister et al., 1998, p. 1252). Instead, SDT argues that when agents experience a sense of autonomy, their energy for subsequent tasks is not diminished (Moller et al., 2006b). Experimental work focused on students' engagement shows greater persistence, more positive self-perceptions, greater engagement, better performance and less dropping out (Jeno and Diseth, 2014; Ryan and Deci, 2000). Similarly, work on employees' engagement confirms these tendencies in terms of job satisfaction, turnover, and well-being at work (Ryan and Deci, 2000). As a general theory of motivation, SDT makes no claim regarding the nature and forms of knowledge and know-how that characterise teaching expertise: it does, however, attribute an essential role to the experience of autonomy in relation to the processes underlying the development of teaching ability and the acquisition of expertise.

When we focus on performance, rather than on the process of acquisition of expertise, we find that the experience of autonomy, as identification, can accompany immersed coping with particular tasks without requiring conscious reflection about actions and rules. This invites us to question models that sharply separate analytic and intuitive thinking and ultimately envisage a dichotomy between two senses of agency. On the one hand these models (Benner, 1996; Dreyfus and Dreyfus, 2005) depict a basic and minimal self-awareness that I am the one causing or generating the action, that I am the author of my movement. This appears to be the kind of basic awareness associated with Dreyfus's immersed coping. This kind of basic experience of agency is distinguished from a reflective phenomenon: the sense of agency I have for my actions because I have a properly ordered set of interpretations of my doing in terms of the beliefs, desires and intentions involved and that would normally explain my actions. The sense of autonomy, as identification, seems to retain the intentional component of the latter, by relating to the agent's goals and beliefs and the meaningfulness of certain tasks. At the same time, it need not be conceived as a 
reflective phenomenon. When we abandon such dichotomies, we allow our everyday phenomenology of the experience of agency to be more ambiguous (Gallagher, 2012) and subject to a variety of disruptions. Identification, or lack of thereof, contributes to this complex sense of agency and, as such, it bears on the agent's immersion and performance.

\section{Authenticity and 'Owning' One’s Practice}

A psychological aspect often cited as a key component of the notion of autonomy is 'authenticity'. 'Authenticity' can be described as being 'true to oneself' or one's values. Unlike the sense of identification, it does not refer to the inherently subjective experience of autonomy. Instead, authenticity connects individuals' attitudes, actions and practices to shared values, identities and modes of life. ${ }^{4}$ In the current discussion, this notion brings to the forefront the idea that teachers are not blank slates or automatons carrying out specific tasks as required by policy mandates. As we shall see, this allows for potential conflict in the various roles they are expected to play. Most importantly, I will show how the notion of authenticity is connected to an ethical dimension of teachers' work that bears on our understanding of teaching expertise.

To start with, however, we need to understand how authenticity is connected to the experience of identification. For example, the extent to which one can identify with some aspect of behaviour is connected to the way in which one can integrate it into one's identity. ${ }^{5}$ In light of this, substantial work has explored how 'teachers' sense of professional, personal identity is a key variable in their motivation, job fulfillment, commitment, and efficacy' (Day, 2002; Rubin and Kazanjian, 2011). These two aspects of autonomy-the psychological element of authenticity and the phenomenological aspect of identification—are crucial if one is to 'own' one's practice.

On the one hand this means that, like moral dispositions and judgements, teaching practices are emotionally charged and correspond to one's understanding of the activity of teaching and one's role as teacher. This emotional involvement bears on 'taking responsibility' for one's successful and unsuccessful choices. In fact, authenticity is considered to be relevant for responsibility, inasmuch as it influences how a certain action reflects on the agent, who she/he is (Arpaly, 2003; Sher, 2009).

Most importantly, this discussion allows us to appreciate how teaching is ultimately a value-laden activity. General debates surrounding education see it as promoting different, sometimes contrasting goals (Ball, 2008; Trowler, 2003), which are connected to different ideologies and policies. Educational ends translate, at a personal level, into a commitment to a certain understanding of one's role as a teacher, defining the value of different concrete aspects of work, priorities and personal goals in practice. Teaching is thus an activity embedded in moral dilemmas and ambiguities, with teachers constantly making choices in their specific contexts. Christopher Jencks (1988) offered a compelling example of how, in practice, teachers elaborate on the principles guiding their work. In relation to educational equity, for example, teachers' intuitions on their commitment to equal opportunities translate into different ways of interpreting the ethical principle and, in practice, different ways of distributing effort, time and attention. Because practices, pedagogies and approaches to subject-knowledge are linked to educational ends, they translate a teacher's ethical outlook into practice: they are imbued with values and they are connected to teachers' commitments to, and purposes for, teaching, to teachers' reasons for becoming and being teachers in the first place. In this sense, practical wisdom can be seen as one of 
the categories that characterises teaching expertise because part of teaching is making not only technical but also value judgements (Biesta, 2009; Biesta et al., 2015). Whether teachers are able to include normative judgements in their practice has much to do with their individual ability for practical wisdom, with the way in which the development of this ability is supported and understood (for example in relation to theoretical knowledge), but also with the structural constraints of their professional work.

Authenticity is hence essential for teachers to own their practice; this in turn entails an ethical dimension of their work that bears on defining teaching ability and raises questions about how to develop and support this ethical dimension of teachers' professionality.

\section{Normative Autonomy and the Goals of Education}

Our discussion so far has stressed how the importance of authenticity and identification for teaching practice derives from the fact that teaching is ultimately a value-laden activity, inextricably connected to educational ends. In fact, these aspects of autonomy seem to play a particular role in the way in which these ends are translated at a personal level in terms of personal goal, motivation and practices. It is important to underscore, however, that educational ends elicit discussion and spark disagreements on both policy and ideology (Sahlberg, 2006; Trowler, 2003): because educational ends are not fixed or rigid facts, they are open to public debate, continually constructed and developed. Education is a political and democratic issue and the open character of its ends raises on-going questions regarding what education is for and how the processes to decide over these issues should be defined.

This invites us to understand a further salient aspect of the concept of autonomy. The discussion so far has revolved around descriptive notions, distinguishing certain conditions and capacities that are normally subsumed under the term. I focus now on normative aspects of the notion, concerning its value and the conditions to promote or respect it.

In normative terms, 'autonomy' can be understood both de jure and de facto. De jure, autonomy is understood as a set of rights to self-government and the person is recognised as a right-holder as well as subject to the duty of respecting the rights of others. On the other hand, having the right to govern ourselves does not mean that we can actually do so. De facto, autonomy means having both the competence and the opportunity to exercise those rights and can thus be understood as personal efficacy. Different theories of what one's rights amount to are associated with different conditions required for someone to count as de facto autonomous (Ashley, 2012; Feinberg, 1989; Raz, 1986).

A normative commitment to autonomy then envisages a particular role for teachers, in relation to their ability to contribute to set educational ends and translate them at different levels of implementation. Such normative commitment does not mean that aims and content of education should be considered as being solely in the hands of teachers. Education, as a public good, sees the public, for example via the government, as possessing vital interests and rights in the matter. Importantly though, an understanding of education as a public good allows a key participatory role for teachers. In fact, recognising this normative aspect of autonomy is essential to legitimate a role of teachers as interlocutors and partners in the construction of the public good as well as in defining their role in relation to their own practices and goals. 
De facto, this means creating the conditions for this autonomy to be developed and exercised: putting in place the conditions that foster competence and opportunity for carrying out this role effectively. A normative commitment to autonomy defines the role of teachers as active developers, designers and creators of various aspects of teaching. ${ }^{6}$ For example, in relation to curriculum design and control, it favours a developmental approach, over a delivery approach (Mausethagen and Mølstad, 2015). This invites us to consider the role of teachers at several levels, from the broader national and system level, for example in relation to defining the educational aims and inputs (Hudson, 2007), to regional and school levels, where the formal curriculum is interpreted in relation to specific programmes and schemes of practice. Another example involves the definition of professional standards. Under this conception of teachers, these standards cannot be externally-defined tools handed off finished in the field: instead, autonomous teachers can be seen as actively engaged in defining such standards, which are conceived epistemically (Mulchay, 2011), and are actively produced in the endeavour to describe shared representations of visions of practice, and to help to identify development opportunities and needs at individual, school level and beyond (EC, 2013).

In all of these cases, the development of the relevant forms of knowledge (for example in relation to curriculum or pedagogy studies, through an active relationship with both theory and empirical research) and know-how are necessary to engage actively in these activities and effectively exercise this role. In turn, the opportunity to develop such forms of expertise refers to the institutional structures that allow for forms of partnership, dialogue and long-term career progression.

To sum up, in this section I have shown how phenomenological aspects of the experience of autonomy and psychological aspects, such as teachers' authenticity, are relevant for teaching by supporting motivation and the development of teaching expertise, while also underscoring the role of value judgements as part of teaching practice. It is important to keep these different meanings of the term autonomy separate if we are to understand their relations. For example, we find substantial support for the idea that a normative commitment to autonomy in defining teachers' role fosters both the sense of autonomy and authenticity. More teachers' involvement at all stages of developing different aspects of teaching makes teachers more likely to feel ownership and boosts motivation (Cribb and Gewirtz, 2007; EC, 2013). Moreover, some commentators equating autonomy with discretion have emphasised the ways in which autonomy takes form at different levels of policy implementation (Frostenson, 2015; Vedung, 2015). From their standpoint, it is claimed that it is possible for practitioners to retain substantial scope for action and latitude to develop coping strategies in face of the particular pressures imposed by regulation. However, through our analysis of the concept of autonomy, we can see how, inasmuch as these coping strategies fundamentally clash with teachers' values and conceptions of their role, they represent losses of autonomy rather than gains. At the same time, they do not alter the fundamentally normative commitments underlying the role of teachers.

These aspects can come apart. On the one hand, a normative commitment to autonomy in our conception of teachers cannot eliminate potential conflicts arising between personal authentic values and those that result from the collective process of negotiation (Biesta et al., 2015). Moreover, different modes of governance and control, coherently with SDT, can have less impact than others on the experience of autonomy. They do not, however, change the normative commitments through which the role of teachers is understood. Similarly, it is possible to see how regulatory arrangements clashing with this role of teachers can succeed at 'colonising teachers' 
subjectivity' (Cribb and Gewirtz, 2007). This phenomenon of adaptation can allow for teachers to be authentic in their practice. It is important to stress these different ways of understanding the idea of autonomy because they provide the basis for conceptually different justifications of policy. They also call for our methodological awareness when employing evidence that captures different aspects of teachers' autonomy.

\section{PROFESSIONAL AUTONOMY IN CURRENT EDUCATIONAL POLICY}

Professional autonomy has been a focal point of education policy debates for quite some time in several countries (Higham and Earley, 2013; Simkins, 2007). For example, reforms in England in the 1980s and the institution of the education quasimarket have been interpreted as a shift from a regime based on trust in professionals to one fundamentally distrusting the public services and employing both top-down approaches and market accountability to regulate and control practice in education (Le Grand, 2007). Professional autonomy has become a prominent topic in the current policy discourse: we find a renewed emphasis on giving 'power and responsibility to teachers on the front line', stressing that the government 'trusts teachers. [Teachers] are the experts on the frontline' (DfE, 2010. The underlying foundation for these claims is what the government calls 'supported autonomy' which explicitly acknowledges teachers' 'professional expertise' (DfE, 2016a, p. 8).

From the standpoint of this paper, what needs further consideration is an analysis of the notion of autonomy implied in this view. In doing so, we need to explore the normative commitments upon which it rests, because these, as we have seen, enable us to define the role of teachers, the conception of teaching and the knowledge and abilities it requires. When the government insists that particular reforms aim to 'give teachers professional autonomy over how to teach', to 'decide how outcomes should be achieved' (DfE, 2016a) we can see that a) autonomy is here understood as fundamentally concerned with means, rather than educational ends: it refers to operational power (defining the 'how' services are provided) rather than criteria power (defining the 'why and what' underlying the purposes of the service, Higham and Earley, 2013, p. 704; Simkins, 1997); and b) it de facto entails a form of bureaucratic independence. This has a pure instrumental value and 'more independence is not an inherent good. Such structural changes are only beneficial in so far as they drive up academic standards' (Gibb, 2015). There is therefore no fundamental contradiction between this form of independence and the fact that schools operate 'under the strictest possible system of oversight and accountability' (DfE, 2016b). At the same time, the conception of teaching that underlies this view is one that promotes forms of localised, informal know-how, with the scope of teaching, as an occupation, fundamentally confined to the execution of tasks in the classroom which are externally prescribed.

Restricting professional autonomy to bureaucratic independence, focusing on the means to attain externally imposed outcomes, leads to defining standards for teachers that ultimately result in a constrained practice and operate under a limited conception of teaching and teaching expertise. The role of teachers here envisaged is one focused on 'delivering excellence' (DfE, 2016a, p. 10), which is externally defined without participation in developing educational ends and related standards, whose link to performance management remains, despite the deep changes that have taken place since the 2010 White Paper The Importance of Teaching (Evans, 2011, p. 853). This is reflected in a prescriptive approach to both pedagogy and curriculum 
design and implementation. In fact, the Teachers' Standards framework (DfE, 2011) in England has contracted to focus on a smaller number of core skills and even greater prescription and policing of its detail in relation to specifics like the teaching of reading by phonics and the management of pupil behaviour (Hulme and Menter, 2011, p. 82; Whitty, 2014, p. 471). This is a feature of the English system that has, in fact, despite the renewed emphasis on autonomy, not altered (Hudson, 2007) and that has placed England on a divergent trajectory in comparison to other UK nations (Beauchamp et al., 2015). It is useful here to focus on a comparison between England and Scotland. While a fully-fledged analysis is not possible, and it is important to stress the difficulties in making comparative judgements between different systems, some broad discrepancies in approach and tendencies are nevertheless illuminating. Scotland has long-established great emphasis on the inclusion of teachers and other stakeholders in the policy process: it displays a 'developmental approach', opposed to a 'regulatory approach' (Menter et al., 2010, p. 16). This must be understood in the context of a 'democratic tradition' in defining the purpose of education that has continued to inform both public attitudes and policy today (Arnott and Menter, 2007). In this sense, not only is the Scottish Curriculum for Excellence a broad framework that 'sees schools and teachers as co-creators of the curriculum' (Donaldson, 2011, p. 4), rather than a prescriptive tool; but teaching is conceived as a research-based profession and Undergraduate ITE programmes in Scotland have been revised in response to Donaldson's critique (p. 39) that the traditional BEd degree had, 'an overemphasis on technical and craft skills at the expense of broader and more academically challenging areas of study' (Beauchamp et al., 2015, p. 164). The latter approach seems essential if teachers are seen as actively participating in the discourse surrounding education policy and its aims. Policy strategy pushes towards the creation of a network of 'hub teaching schools as a focal point for research, learning and teaching' (Donaldson, 2011, p. 91), extending the role for university-based educators in partnership with local authorities. It is important to stress the difficulties in building, de facto, the capacity for teachers to play such active and autonomous roles. Autonomy is demanding: what this approach requires is the development of longterm, well-defined routes of career progression that allow teachers to move along and engage at different levels of policy implementation. Menter et al. (2010) find that there is scope for a much more integrated approach to teacher education across the career course and better development of partnerships between the various contributors to teacher education.

There remains, however, a particularly striking opposition between this approach and the tendencies towards both centralisation and fragmentation that we find in England: not only do these seem to display little effort to develop consensus among key stakeholders, including teachers, but we find a preference for apprentice models of school-based learning, for example through the replacement of the 'Qualified Teacher Status' accreditation with one based on a teacher's effectiveness in the classroom (DfE 2016a, p. 24), and programmes such as Teach First (Maxwell, 2015). ${ }^{7}$

Furthermore, the conception of autonomy, as bureaucratic independence, employed in this policy discourse can hardly be used to engage with the growing literature reporting on the impact of what has been deemed a 'performativity culture' (Ball, 2003) on teachers' morale and motivation. According to the analysis this paper proposes, we can frame complaints of low morale and motivation in terms of losses of autonomy, in psychological terms, as authenticity, and in terms of the experience of identification. In particular, greater individualisation of pay and pay for performance 
schemes, which are envisaged by current policies (Cirin, 2014, p. 48; DfE, 2016a, p. 12), have long been considered by theories such as SDT to reduce these forms of autonomy. In light of the particular problems of attrition that plague the English system, these considerations deserve deeper attention.

In practice, there is a substantial variation in how different schools are subject to inspection and direct control (Higham and Earley, 2013); we can expect, from the standpoint of the experience of autonomy, differences corresponding to these different pressures. It is important, however, to notice that this does not alter the overall underlying conception of teachers' role and related expertise. If anything, this progressive fragmentation of the school system, fosters the construction of teachers as prepared to work within a particular school or group of schools, relying on a type of practical knowledge that is local and informally acquired in a particular environment, rather than in the system as a whole. In turn this sharpens the fragmentation of teaching, left without a role in the broader system, with their activity narrowly confined to the classroom.

Moreover, the emerging differences among schools in the fragmented English system raise further worries: Higham and Earley (2013) notice that disadvantaged intakes are underrepresented in schools that have more discretion in relation to certain aspects of policy. This is something that, taken in conjunction with the extensive literature that connects school composition to high levels of achievement (van Zanten, 2005), the very condition that grants looser oversight, poses questions regarding the justification of inequalities of autonomy for teachers in different institutions.

To sum up, through this discussion we can see that, in face of the public rhetoric that finds the term 'autonomy' at the forefront of discussion, the normative commitments of current policies do not represent a break from the 'distrust regimes' of the past. On the contrary, current policies seem to hinder several aspects of autonomy and can actually bear on teaching expertise. Policy measures produce in teachers the sense of feeling detached, alienated or passive, hindering motivation and wellbeing, but also redefine teaching practice, changing the nature of the work, creating clashes with individuals' deeper values and their own conception of their role. Ultimately, different normative commitments to teachers' autonomy underlie a different conception of teachers and bear on how we understand their occupational expertise: they shape conceptions of the forms of teaching as an activity, because they establish a different relationship between agents/teachers and educational ends. As pointed out in the last section, vivid debates surrounding the goals of education underlie much of the politics and policy discussion. The fact that teachers, while acknowledged as 'experts', seem to be fundamentally marginalised in these debates shows a particular understanding of their expertise, of what teachers are for and hence of what forms of knowledge and abilities should be developed. The resistance we find in relation to high-stakes testing and accountability measures can thus be better understood as concerning the normative place of professionals in the public discourse and their role in defining educational outcomes, goals and quality. Opposed to the active and participatory role that underlies a normative commitment to autonomy, the emphasis on mere instrumental independence seems to construct teachers as clerks or technicians, ${ }^{8}$ with no need for public vision. While it might seem plain that teaching involves agency, this paper has argued that the forms of this agency can be interpreted in various ways and relate to the scope of teaching as an occupation. In turn, these entail different forms of occupational expertise. At the same time, our discussion has invited us to problematise the way in which different roles attributed to practitioners translate at the personal level. 
Correspondence: I. Bucelli, Centre for Analysis of Social Exclusion, London School of Economics and Political Science, Houghton Street, London WC2A 2AE (UK).

Email: i.bucelli@lse.ac.uk

\section{NOTES}

1. This is particularly the case for those models that equate reflection with deliberation and incur substantial problems for example by unduly restricting the range of what counts as actions (Bucelli, 2014), while also appearing vulnerable to to a regress objection. See Arpaly and Schroeder, 2012, p. 220 for the latter.

2. Importantly, according to these views of agency, post hoc rationalisation would not suffice for agency. See my discussion of this view in Bucelli, 2014. Moreover, it is important to note that the views of autonomy I just presented rely on a distinctive Kantian legacy, tying autonomy to rationality. As a result, autonomy seems to play no role in actions which, according to Dreyfus, by virtue of displaying a level of expertise, should be considered arational.

3. For further discussion of ego-depletion see also Levy, 2007, pp. $206-214$.

4. In this sense, authenticity is also to be distinguished from the form of agential control over one's motives that is associated with the notion of autonomy in several accounts, especially of neoKantian inspiration. For a critique of this notion of control as a necessarily individualistic notion, see Macintyre, 1981, p. 42. The notion of authenticity does not deny that our identities are always forged through the communities to which we belong, which in turn each have histories. Moreover, it does not require explicit endorsement.

5. At the same time the two phenomena need not always be aligned. For a discussion of this in relation to 'akrasia’ see Bucelli, 2014.

6. Winch, 2017 explores in detail different conceptions of the roles of teachers (as craftworkers, as executive technicians, as professional technicians). His considerations about professional technicians are particularly relevant here.

7. It is important to notice that while we find, in the English context, emphasis on teachers being 'evidence-informed', there is no clear indication of how teachers are to be equipped to engage with this research and the DfE strategy emphasises the role of bodies (such as the Education Endowment Foundation) outside the university system to provide 'evidence on what works' (DfE, 2016a, p. 13).

8. These considerations invite us to engage with the rich debates surrounding different conceptions of occupations, the particular goals and ends that define them and their standards of excellence, which cannot be adequately addressed here (see Winch, 2017, ch .4)

\section{REFERENCES}

Arpaly, N. (2003) Unprincipled Virtue (Oxford University Press, Oxford). 
Arpaly, N. and Schroeder, T. (2012) Deliberation and Acting for Reasons, Philosophical Review, 121.2, pp. 209-239.

Arnott, M. and Menter, I. (2007) The Same but Different? Post-devolution Regulation and Control in Education in Scotland and England, European Educational Research Journal, 6.3, pp. 250-265.

Ashley, V. (2012) Philosophical Models of Autonomy, Essex Autonomy Project Green Paper Report (University of Essex, Essex Autonomy Project).

Ball, S.J. (2003) The Teacher's Soul and the Terrors of Performativity, Journal of Education Policy, 18.2, pp. 549-566.

Ball, S. (2008) The Education Debate: Policy and Politics in the 21st Century (London, Routledge).

Barksdale-Ladd, M.A. and Thomas, K. (2000), What's at Stake in High-Stakes Testing: Teachers and Parents Speak Out, Journal of Teacher Education, 51.5, pp. 384-397.

Baumeister, R. F., Bratslavsky, E., Muraven, M. and Tice, D. (1998) Ego depletion: Is the active self a limited resource? Journal of Personality and Social Psychology, 74, pp. 1252-1265.

Benner, P., Tanner, C. and Chesla, C. (1996) Expertise in nursing practice: Caring, clinical judgment, and ethics (New York, Springer Publishing).

Ben-Porath, S. R. (2009) School Choice as a Bounded Ideal, Journal of Philosophy of Education, 43, pp. 527-544.

Berliner, D.C. (1994) Expertise: The Wonders of Exemplary Performance, in Mangieri, J.N and Block, C.C. (eds.) Creating Powerful Thinking in Teachers and Students (New York, Holt, Rinehart and Winston), pp. 144-186.

Berliner, D. C. (2001) Learning about and Learning from Expert Teachers, International Journal of Educational Research, 35, pp. 463-482.

Beauchamp, G., Clarke, L. Hulme, M. and Murray, J. (2015) Teacher Education in the United Kingdom Post Devolution: Convergences and Divergences', Oxford Review of Education, 41.2, pp. 154-170.

Biesta, G.J.J. (2009) Values and Ideals in Teachers' Professional Judgement', in S. Gewirtz, P. Mahony, I. Hextall and A. Cribb (eds.) Changing Teacher Professionalism (London, Routledge), pp. 184-193.

Biesta, G. J. J. (2015) How Does a Competent Teacher Become a Good Teacher? On Judgement, Wisdom and Virtuosity in Teaching and Teacher Education, in R. Heilbronn and L. ForemanPeck (eds.) Philosophical Perspectives on the Future of Teacher Education (Oxford, Wiley Blackwell), pp. 3-22.

Biesta, G., Priestley M. and Robinson S. (2015) The Role of Beliefs in Teacher Agency, Teachers and Teaching, 21.6, pp. 624-640.

Bratman, M. (2007) Structures of Agency: Essays (Oxford, Oxford University Press).

Brighouse, H. (2002) School Choice and Social Justice (Oxford, Oxford University Press).

Bucelli, I. (2014) Kinds of Agency and the Role of Reflective Endorsement, Doctoral Thesis, King's College London.

Christman, J. (1998) Autonomy, Independence and Poverty-related Welfare Policies, Public Affairs Quarterly, 12.4, pp. 382-405. 
Cirin, R. (2014) Do Academies Make Use of their Autonomy? Department of Education Research report. DfE-RR366.

Coleman, J. (2003) School Choice, Diversity and a Life of One's Own, Theory and Research in Education, 1.1, pp. 101-120.

Cribb, A., and Gewirtz, S. (2007) Unpacking Autonomy and Control in Education: Some Conceptual and Normative Groundwork for a Comparative Analysis, European Educational Research Journal, 6.3, pp. 203-213.

Day, C. (2002) School Reform and Transitions in Teacher Professionalism and Identity, International Journal of Educational Research, 37, pp. 677-692.

Deci, E. and Ryan. R. (2000) The 'What' and 'Why' of Goal Pursuits: Human Needs and the SelfDetermination of Behaviour, Psychological Enquiry, 11.4, pp. 227-268.

Department for Education (2010) The Importance of Teaching, White Paper, (London: Her Majesty’s Stationary Office).

Department for Education (2011) Teachers' Standards Guidance for School Leaders, School Staff and Governing Bodies (London: Her Majesty’s Stationary Office). Available online at: www.gov.uk/governmentpublications.

Department of Education (2016a) Educational Excellence Everywhere, White Paper, (London: Her Majesty’s Stationary Office).

Department for Education, (2016b) Landmark education bill completes passage through Parliament (London: Her Majesty’s Stationary Office). Available online at: https://www.gov.uk/government/news/landmark-education-bill-completes-passage-throughparliament.

Donaldson, G. (2011) Teaching Scotland's Future (Edinburgh, The Scottish Government).

Dreyfus, H. L. (2002) Refocusing the Question: Can There Be Skillful Coping Without Propositional Representations or Brain Representations? Phenomenology and the Cognitive Sciences, 1, pp. 413-425.

Dreyfus, H. L. and Dreyfus, S. E. (1988) Mind over Machine: The Power of Human Intuition and Expertise in the Era of the Computer (New York, Free Press).

Dreyfus, H.L. and Dreyfus, S.E. (2004) The Ethical Implications of the Five-Stage Skill-Acquisition Model, Bulletin of Science Technology and Society, 24.3, pp. 251-264.

Dreyfus, H. L. and Dreyfus, S. E. (2005) Expertise in Real World Contexts, Organization Studies, 26, pp. 779-792.

Dreyfus, S.E. (2004) The Five-Stage Model of Adult Skill Acquisition, Bulletin of Science Technology and Society, 24, pp. 177-181.

Dworkin, G. (1989) The Concept of Autonomy, in Christman J. (ed.) The Inner Citadel: Essays on Individual Autonomy (New York, Oxford University Press), pp. 54-62.

European Commission (2013) Supporting Teacher Competence Development: Development for Better

Learning Outcomes (Strasbourg: European Commission Directorate-General for Education and

Culture). Available from:

http://ec.europa.eu/dgs/education_culture/repository/education/policy/school/doc/teachercomp_en.pdf 
Evans, L. (2011) The 'Shape' of Teacher Professionalism in England: Professional Standards, Performance Management, Professional Development and the Changes Proposed in the 2010 White Paper, British Educational Research Journal, 37.5, pp. 851-870.

Feinberg, J. (1989) Autonomy, in Christman J. (ed.) The Inner Citadel: Essays on Individual Autonomy (New York, Oxford University Press), pp. 27-53.

Frostenson, M. (2015) Three Forms of Professional Autonomy: De-Professionalisation of Teachers in a New Light, Nordic Journal of Studies in Education Policy, 1, pp. 20-29.

Frankfurt, H. (1971) Freedom of the Will and the Concept of Person, Journal of Philosophy, 68, pp. 520.

Frankfurt, H. (1986) The Importance of What We Care About, in Frankfurt, H. The Importance of What We Care About: Philosophical Essays (Cambridge, Cambridge University Press), pp. 8094.

Gallagher S. and Marcel, A. (1999) The Self in Contextualized Action, in S. Gallagher and J. Shear (eds.) Models of the Self (Exeter, Imprint Academic), pp. 273-300.

Gallagher, S. (2012) Multiple Aspects of Agency, New Ideas in Psychology, 30, pp. 15-31.

Gibb, N. (2015) How Autonomy Raises Standards, Speech at FASNA conference, 12 November 2015. Available online at: https://www.gov.uk/government/speeches/how-autonomy-raises-standards

Gutman, A. (1995) Civic Education and Social Diversity, Ethics, 105, pp. 557-579.

Haydon, G. (1983) Autonomy as an Aim of Education and the Autonomy of Teachers, Journal of Philosophy of Education, 17.2, pp. 219-228.

Higgins, C. (2011) The Good Life of Teaching (Oxford, Wiley-Blackwell).

Higham, R. and Earley, P. (2013) School Autonomy and Government Control: School Leaders’ Views on a Changing Policy Landscape in England, Educational Management Administration and Leadership, 41.6, pp. 701-717.

Hudson, C. (2007) Governing the Governance of Education: the State Strikes Back? European Educational Research Journal, 6.3, pp. 266-282.

Hulme, M. and Menter, I. (2011) South and North - Teacher Education Policy in England and Scotland: a Comparative Textual Analysis, Scottish Educational Review, 43.2, pp. 70-90.

Jacob, B. A. (2004) Accountability, Incentives and Behavior: the Impact of High-Stakes Testing in the Chicago Public Schools, Journal of Public Economics, 89.5-6, pp. 761-796.

Jencks, C. (1988) Whom Must We Treat Equally for Educational Opportunity to Be Equal? Ethics, 98, pp. 518-533.

Jeno, L. M., and Diseth, Å. (2014) A Self-Determination Theory Perspective on Autonomy Support, Autonomous Self-Regulation and Perceived School Performance, Reflecting Education, 9.1, pp. $1-20$.

Korsgaard, C. (2009) Self-constitution. Agency, Identity and Integrity, (Oxford, Oxford University Press).

Le Grand, J. (2007) The Other Invisible Hand: Delivering Public Services through Choice and Competition (Princeton, NJ, Princeton University Press). 
Levy, N. (2007) Neuroethics: Challenges for the $21^{\text {st }}$ Century (Cambridge, Cambridge University Press).

MacIntyre, A. (1981) After Virtue (Notre Dame, University of Notre Dame Press).

Mausethagen, S. and Mølstad, C. (2015) Shifts in Curriculum Control: Contesting Ideas of Teacher Autonomy, Nordic Journal of Studies in Education Policy, 1, pp. 30-41.

Maxwell, B. (2015) 'Teacher as Professional' as Metaphor: What it Highlights and What It Hides, Journal of Philosophy of Education, 49.1, pp. 86-106.

Menter, I., Hulme, M., Elliot D. and Lewin, J. (2010) Literature review on teacher education in the $21^{\text {st }}$ Century, (Edinburgh: Education Analytical Services).

Moller, A. C., Deci, E. L., and Ryan, R. M. (2006a) Choice and Ego Depletion: The Moderating Role of Autonomy, Personality and Social Psychology Bulletin, 32, pp. 1024-1036.

Moller, A.C., Ryan, R.M. and Deci, E.L. (2006b) Self-Determination Theory and Public Policy: Improving the Quality of Consumer Decisions Without Using Coercion, Journal of Public Policy and Marketing, 25.1, pp. 104-116.

Morgan, J. (1996) A Defence of Autonomy as an Educational Ideal, Journal of Philosophy of Education, 30.2, pp. 239-252.

Mulchay, D. (2011) Assembling the 'Accomplished' Teacher: The Performativity and Politics of Professional Teaching Standards, Educational Philosophy and Theory, 43.1, pp. 94-113.

Raz, J. (1986) The Morality of Freedom (Oxford, Oxford University Press).

Reich, R. (2002) Bridging Liberalism and Multiculturalism in American Education (Chicago, IL, Chicago University Press).

Rubin, D.I. and Kazanjian, C.J. (2011) 'Just Another Brick in the Wall': Standardization and the Devaluing of Education, Journal of Curriculum and Instruction, 5.2, pp. 94-108.

Ryan, R. and Deci, E. (2000) Intrinsic and Extrinsic Motivations: Classic Definitions and New Directions, Contemporary Educational Psychology, 25, pp. 54-67.

Ryan, R. and Deci, E. (2006) Self-Regulation and the Problem of Human Autonomy: Does Psychology Need Choice, Self-Determination, and Will? Journal of Personality, 74.6, pp. 1557-1585.

Sahlberg, P. (2006) Education Reform for Raising Economic Competitiveness', Journal of Educational Change, 7.4, pp. 259-287.

Sartre, J. (1946) Existentialism is a Humanism (New York, Philosophical Library).

Sher, G. (2009) Who Knew? Responsibility Without Awareness (Oxford, Oxford University Press).

Simkins T (2007) Autonomy and Accountability, in Fidler B, Russell S. and Simkins T (eds.) Choices For Self-Managing Schools: Autonomy and Accountability (London, BEMAS).

Trowler, P. (2003) Education Policy (London, Routledge).

van Zanten, A. (2005) New Modes of Reproducing Social Inequality in Education: the Changing Role of Parents, Teachers, Schools and Educational Policies, European Educational Research Journal, 4.3, pp. 155-169.

Vedung, E. (2015) Autonomy and Street-Level Bureaucrats' Coping Strategies, Nordic Journal of Studies in Education Policy, 1, pp. 15-19.

Velleman, D. (2007) Practical Reflection (Stanford, CA, CSLI Publications). 
Webb, R., Vulliamy, G., Hämäläinen, S., Kimonen, E. and Nevalainen, R. (2004) A Comparative Analysis of Primary Teacher Professionalism in England and Finland, Comparative Education 40.1, pp. 83-107.

Wermke, W. and Salokangas, M. (2015) Autonomy in education: Theoretical and Empirical Approaches to a Contested Concept, Nordic Journal of Studies in Education Policy, 1, pp. 1-6.

West, A. and Pennell, H., (2005) Market-oriented Reforms and 'High-Stakes’ Testing: Incentives and Consequences, Cahiers de la recherche sur l'éducation et les savoirs, 1, pp. 181-199.

White, J. (2003) Five Critical Stances Towards Liberal Philosophy of Education in Britain, Journal of Philosophy of Education, 37.1, pp. 147-184.

Whitty, G. (2014) Recent Developments in Teacher Training and their Consequences for the 'University Project' in Education, Oxford Review of Education, 40.4, pp. 466-481.

Wilson, T.S. and Ryg, M.A. (2015) Becoming Autonomous: Non-ideal Theory and Educational Autonomy, Educational Theory, 65.2, pp. 127-150.

Winch, C. (2002) Strong Autonomy and Education, Educational Theory, 52.1, pp. 27-41.

Winch, C. (2009) Ryle on Knowing How and the Possibility of Vocational Education, Journal of Applied Philosophy, 26.1, pp. 88-101.

Winch, C. (2010) Dimensions of Expertise (London, Continuum).

Winch, C. (2017) Teachers' Know-how. A Philosophical Investigation (Chichester, Wiley-Blackwell). 